\title{
Earnings Management (EM), Initiatives and Company Size: An Empirical Study
}

\author{
Anna Siekelova $^{1}$, Armenia Androniceanu' ${ }^{2}$, Pavol Durana ${ }^{1}$, \\ Katarina Frajtova Michalikova ${ }^{1}$
}

${ }^{1}$ University of Zilina, Faculty of Operation and Economics of Transport and Communications, Department of Economics, Univerzitna 8215/1, 01026 Zilina, Slovakia, anna.siekelova@fpedas.uniza.sk,pavol.durana@fpedas.uniza.sk, fmichalikova@fpedas.uniza.sk

${ }^{2}$ Bucharest University of Economic Studies, International Centre for Public Management, 11, Tache Ionescu, Bucharest, Romania, University of Social Sciences, 9 Sienkiewicza St. 90-113, Lodz, Poland, armenia.androniceanu@man.ase.ro

Abstract: This paper deals with the issues of Earnings Management. Earnings Management (hereafter "EM") can be stated as a modern phenomenon, in recent years. Under the influence of globalization, new ideas penetrate this theory. This topic remains one of the most controversial topics of current financial theories or accounting. The accounting procedures allow managers to exercise their judgment and to make subjective estimates, to a certain extent, when designing financial statements. When this freedom is used correctly, it can be helpful in the process of improving the relevance and reliability of financial statements and reducing information asymmetry. Conversely, the opportunistic use of this freedom can contribute to the exact opposite result - lower relevance and reliability of financial statements, as well as, higher asymmetry of information. The aim of this work is EM initiatives analysis, statistical verification of the existence of the relationship between EM and company size, defined by chosen criteria and provide conclusions with regard to results. The first theoretical part of the paper deals with the theoretical basis of EM. Within the practical part of the contribution, the authors try to detect the presence of earning management based on the calculation of accruals, structured as discretionary and nondiscretionary accruals, in the sample of enterprises using a modified Jones model and to verify the existence of the relationship between EM and company size, using the one-way ANOVA test. The differences in the sample averages are too large to be random, it is shown that there is a statistically significant difference in the level of EM, regarding company size.

Keywords: earnings management; accrual-based EM; company size; modified Jones model; the one-way ANOVA test 


\section{Introduction}

Academic community has started dealing with the issue of practice of earnings management (hereafter "EM") since at least the 1960s. The first works focused on the impact of accounting choices on capital markets. [1] There were stated the socalled, mechanistic hypothesis. These type of hypothesis predict that investors ignore differences in accounting policy choice and fixate on reported numbers. It shows that investors who do not take into account other financial reports, as a source of information, are sometimes misled by using EM initiatives, in the form of accounting directions. [2, 3, 4] If we assume that the mechanistic hypothesis was dominate, investors believed that their stock prices increased only as a result of higher reported earnings in the company. It is the chance to think that investors could be misled through manipulating accounting data, intentionally, by managers. On the other hand, the efficient market hypothesis predict that the share price is influenced by publicly available information, including the choice of accounting policy on profit. $[5,6,7,8]$ The efficient market hypothesis started to dominate in 1970s. It follows that stock prices are influenced by all available information in an efficient capital markets. Results of initial studies why EM exist were inconclusive. Based on the later polished study [9] research of earnings management were shifted from capital to non-capital markets. The name of the study is Positive Accounting Theory and was published by authors Watts and Zimmermann in 1978. The basis of the study was the assumption of rational manager's existence. Their rationality lies in the effort to influence financial outcomes for their interests by using appropriate accounting method. Since the 1990s, the research of the earnings management issue has moved back from noncapital to capital market. It highlights the importance of the economic consequences of EM initiatives on resource allocation on the capital market.

Many older, as well as, current studies show the importance of the implementation of the earnings management. Most of them are focused mainly on developed countries. $[10,11,12,13,14,15,16,17,18,19,20]$ Authors Burgstahler and Dichev examined the relationship between EM and firm's losses in a sample of three hundred entities. They found out that large and small entities, manage earnings in cases to prevent small profits or losses. [21] Author Rangan verified the existence of a statistically significant relationship between performance of experienced equity offerings and EM. He examined that the largest companies that had long been operating in the market, he suggested that the older and the largest companies were adjusted current accruals in order to gain profits from the stock experience. [22] Authors Lee and Choi stated that larger firms faced more influence to get the analysts' demands to manage earnings more effectively. [23] Some authors tried to show that auditors sometimes consciously overlook EM initiatives of large companies. Their studies show a positive correlation between audit fees and company size and a negative correlation between adjustments in the financial statements by the auditors and company size. Kim, Udawatte and Yin verified the relationship between corporate EM and the company size. They claim 
that company size has a positive impact on EM initiatives. [24] Fewer studies analyze the issue of EM in emerging or developing countries. The contribution consists of two parts. There is a theoretical background of earnings management, its history, definitions, forms, and motives. Further, the basic mathematical and statistical procedures used in the practical part in the verification of described hypotheses. The practical part of our work is focused on the impact of company size on EM under the condition of the emerging market. The aim of our work is EM initiatives analyzing, statistical verification of the existence of the relationship between EM and company size defined by chosen criteria and providing conclusion with regard to results.

\section{Theoretical Background}

The first ways to capture Earnings Management are based on graphical methods based on time-series data (Gordon, Dopuch, Drake or Archibald). Another group of authors dealt with the detection of EM by mathematical modeling of specific accruals (Copelamd, White, Barefield, Comiskey, Dascher, Malcom or Beidleman). The third group of authors detects earnings management through mathematical modeling of total discretionary accruals using time series data (Healy, Kaplan, DeAngelo, Wilson, Jones, Dechow, Kothari, Watts, Beneish or Young). Another group was authors who decided to use cross-sectional abnormal accruals instead of time series data, namely DeFond, Jiambalvo, Subramanyam, Pope or Young. Beneish constructed a model detecting earnings manipulation similar to Altman's bankruptcy model. Especially after 2000, the group of authors (Dechow, Skinner, Grahamet, Penman or Zhang) has dealt with the issue of socalled real earnings management. Cho, Choi and Kwon dealt with the role of employee on financial reporting. They investigated the relationship between real EM and employee length of employment. [25] Authors Hamza and Kortas dealt with the impact of weaker regulatory environment on EM. [26] Jeong and Choi showed the existence of the negative association that real EM prevents the market from assessing companies' future earnings reflected in the current stock prices. [27] The results of work by Kim, Udawatte and Yin [24] shows that the higher the CSR level is, the lower the EM initiatives level are in the company. In connection with the development of information and communication technologies, also modeling using neural networks penetrates into the issue of earnings management. $[28,29,30]$

\subsection{Definitions of Earnings Management}

Achieved economic result can be considered as a tool for measurement of the company performance during the year. It is set as the difference between revenues and costs of the fiscal year. There are many situations in which achieved 
economic results are intentionally influenced by managers. These initiatives on the accounting earnings are also known as earnings management. [31] There are several definitions of the earnings management, in particular depending on the positive or negative understanding of the concept by the authors. The authors Ronen and Yaari offer a comprehensive view of the issue of different understanding of the term in their publications Earnings Management - Emerging Insights in Theory, Practice, and Research. [32] They summarized definitions of EM and divided them into the three groups, namely:

- White EM

- Gray EM

- Black EM

White EM takes into account the ability to use the flexibility in choosing an accounting policy to signal a manager's private information about future cash flow. Gray EM takes into account that the ability to use the flexibility in choosing an accounting policy can lead to maximizing economically efficient or the manager's utility. In these cases, EM is used as a tool for achieving the goals set by management [32] Black EM is defined as initiatives to misrepresent or reduce the relevance and reliability of financial reports. The intention to use earnings management techniques is still not clearly defined. Therefore, it is difficult to clearly identify only one of the three types of mentioned types of EM that the company uses. It is also possible that, at different stages, it uses EM techniques for a different purpose and thus the dedicated EM types can overlap. Definition created by Healy and Wahlen captures both approaches, the costly, Contracting (company uses EM to influence contractual outcomes) and the Informational (company uses EM to mislead investors). There is no specified boundary between EM initiatives and common activities influencing earnings. [32] Authors Ronen and Yaari define EM as a set of activities performed by managers in an effort to not reporting true, value-maximizing, short-term earnings in the form that are known to business management. [32]

\subsection{Forms of Earnings Management}

According to studies, there are two different ways that earnings in the company can be managed. [33, 34, 35, 36, 37, 38, 39] Reported earnings can be influenced through discretionary accruals activities allowed under GAAP. It is also known as Accrual-based Earnings Management (hereafter “AEM”). Accrual-based earnings management can be observed especially after most of the real operating activities are done toward the end of an accounting period. Two types of accruals can be distinguished, non-discretionary accruals, as well as, discretionary accruals. Nondiscretionary accruals are determined by the normal economic situation of the company. On the other hand, discretionary accruals are the manager's choice policy not regulated in the contract. It can be state that discretionary accruals are 
the result of manager's opportunism. The amount of accounting accruals is influenced by AEM, while AEM has direct impact on cash flows. On the other hand, reported earnings can be manipulated by structuring real activities. This practice is also known as Real Earnings Management (hereafter "REM"). During the accounting period, timing or scale of real activities (such as sales, financing, investment, production) can be managed with the intention to achieve a specific earnings goals. Achieved economic results are sometimes influenced by chosen activities such as accelerating the timing of production, cutting discretionary expenditures, deferring the timing of expenditures and so on. REM activities can be most often seen as the effort to reduce R\&D expenditures to decrease reported expenses. Significant work dealing with REM is Earnings management through real activities manipulation by Sugata Roychowdhury. His research was focused on seeking evidence that managers use REM activities to avoid reporting annual loses. He also dealt with the idea that price discounts increase sales temporarily, lower costs of sold products or services are reported due to the overproduction and decreasing discretionary expenditures to improve reported margins can be seen. [40] Roychowdhury distinguishes three ways how REM can be done, namely sales manipulation, manipulation by reducing discretionary expenses, and manipulation through the production process by overproduction. [40] REM activities have a direct impact on current as well as future cash flow and it is also more complicated to recognize REM activities for average investors as well as the auditors or regulators - it can be seen as an advantage of this EM form. [40] The impact on company future cash flow can be perceived negatively as a disadvantages of REM activities. These activities must be really anticipated by stakeholders because it endangers the survival of the company. Kim, Udawatte and Yin state that while REM activities has impact on executive compensation, AEM does not influence it. [24] REM has not been as widely studied as AEM. Current researches deals with an idea that managers prefer REM activities, by such means as reducing discretionary expenditures, over AEM as a way to manage achieved economic results. [41, 42, 43, 44]

\subsection{Motives for Earnings Management}

The three main theories, namely Contracting Theory, Bounded Rationality Theory and Information Asymmetry Theory, which describe motives of EM activities in the company. The following Table 1 shows the main earnings management motives derived from mentioned theories.

Table 1

The main earnings management motives. Source: own research based on [45]

\begin{tabular}{|c|c|c|c|}
\hline Theory & Contracting Theory & $\begin{array}{c}\text { Bounded } \\
\text { Rationality Theory }\end{array}$ & $\begin{array}{c}\text { Information } \\
\text { Asymmetry Theory }\end{array}$ \\
\hline Motives - group & $\begin{array}{c}\text { Contracting } \\
\text { Motives }\end{array}$ & $\begin{array}{c}\text { Capital Market } \\
\text { Motives }\end{array}$ & External Motives \\
\hline
\end{tabular}




\begin{tabular}{|c|c|c|c|}
\hline \multirow{8}{*}{ Factors } & $\begin{array}{l}\text { Management } \\
\text { compensation }\end{array}$ & Stock market & Industry \\
\hline & CEO turnover & $\begin{array}{l}\text { Issuance of equity } \\
\text { (in case of } \\
\text { IPO/SEO) }\end{array}$ & $\begin{array}{c}\text { Industrial } \\
\text { diversification }\end{array}$ \\
\hline & Managerial ability & $\begin{array}{l}\text { New listing and } \\
\text { cross-listing }\end{array}$ & Regulations \\
\hline & $\begin{array}{l}\text { Corporate } \\
\text { governance }\end{array}$ & $\begin{array}{l}\text { Mergers and } \\
\text { acquisitions }\end{array}$ & $\begin{array}{l}\text { Political environment } \\
\text { and country-specific } \\
\text { policies }\end{array}$ \\
\hline & Loans & Insider trading & $\begin{array}{c}\text { Accounting } \\
\text { standards }\end{array}$ \\
\hline & \multirow{3}{*}{ Firm characteristics } & $\begin{array}{c}\text { Management } \\
\text { buyouts }\end{array}$ & Tax considerations \\
\hline & & $\begin{array}{l}\text { Meeting or beating a } \\
\text { benchmark }\end{array}$ & Competitors \\
\hline & & Analysts & $\begin{array}{l}\text { Suppliers and } \\
\text { customers }\end{array}$ \\
\hline
\end{tabular}

\section{Hypothesis Development and Methodology}

This part of our contribution describes the used techniques, methods and hypothesis development. Authors used the Amadeus database to obtain data for their research. Sampling criteria were adapted regarding to the aim of contribution. Data covers 2018. The financial statements of the Visegrad Four countries have been selected. Authors updated the sample several times, by excluding companies due to incomplete data necessary for the calculation of formulas, as well as, by excluding companies that were marked as canceled in the monitored year, in liquidation, restructuring, resp. were not found. Finally, authors also excluded from the database companies whose values were determined as an outliers by using Grubbs' test. The remaining number of enterprises was 1,548.

As was mentioned above, there are several techniques for measuring earnings management. One group consists of discretionary accrual estimation models. Based on this type of techniques EM initiatives are calculated by detecting discretionary accruals. Discretionary accruals are known as a part of total accruals therefore it is necessary to calculate them. There are two different ways how to do it. Based on current literature, the balance sheet approach and the statement of cash flows approach can be distinguished. [28] The balance sheet approach is widely used. The sum of total accruals is calculated by using following formula.

$$
T A=\Delta C A-\triangle C L-\triangle C a s h+\triangle S T D-D e p
$$

Where: 
$T A$

$\triangle C A$

$\triangle C L$

$\Delta$ Cash

$\triangle S T D$

Dep the sum of total accruals

the year-on-year change in current assets

the year-on-year change in current liabilities

the year-on-year change in cash and cash equivalents

the year-on-year change in the current maturities of long-term debt and other short-term debt included in current liabilities

depreciation and amortization expenses

The standard Jones model was denoted as the most used discretionary model. The essence of this model is the decomposition the sum of total accruals to nondiscretionary accruals (hereafter "NDA") and discretionary accruals (hereafter "DA"). To estimate DA, it is necessary to run a regression with the dependent variable TA. The total accrual is estimated using the formula by Hoglund. This model can be applied to both cross-sectional data and time series. NDA are estimated by the model, residuals are DA. The use of the modified Jones model can be possibly recognized in current research. The difference is that changes in sales are adjusted for the change in receivables. [46] The standard Jones model has been modified to decrease the measurement error of DA when discretion is applied over sale. There are also some studies that prove that the modified Jones model is the most powerful technique to indicate EM initiatives compared to the others (e.g. industry model, Healy DeAngelo model or standard Jones model). Based on the modified Jones model, discretionary accruals estimation is calculated using the following formulas.

$$
\begin{gathered}
\frac{T A_{i t}}{A_{\mathrm{it}-1}}=\alpha_{0} \frac{1}{A_{\mathrm{it}-1}}+\alpha_{1} \frac{\Delta R E V_{i t}-\Delta R E C_{i t}}{A_{i t-1}}+\alpha_{2} \frac{P P E_{i t}}{A_{i t-1}}+\varepsilon_{i t} \\
T A=N D A+D A
\end{gathered}
$$

Where:

$T A_{i t} \quad$ the sum of total accruals in year $t$

$A_{\text {it-1 }}$ the sum of assets in year $t-1$

$\triangle R E V_{i t}$ the change in revenues between years $t$ and $t-1$

$\triangle R E C_{i t}$ the change in receivables between years $t$ and $t-1$

$P P E_{i t}$ the sum of the property, plant $\&$ equipment in year $t$

$\varepsilon_{i t}$ statistical error

$N D A$ non-discretionary accruals

$D A$ discretionary accruals

DA calculated by the modified Jones model are also known as abnormal accruals. These accruals are used as an estimation of the EM initiatives. The higher the 
value of DA is, the lower is the quality of reported achieved earnings. Based on the previous defining DA, the hypothesis was developed.

$\mathrm{H}_{0} \quad \mu_{\text {Discretionary Accruals }}=\mu_{\text {Total Assets }}$

$\mathrm{H}_{\mathrm{a}} \quad$ The means are not all equal

Note: The amount of DA was used as an estimation for detecting EM initiatives in the companies. The amount of natural logarithm of total assets was used as an estimation for company size. Choice the amount of natural logarithm of total assets as a criterion for company size measurement is supported by many researchers and many works. Almost a half of papers use total assets, market capitalization, sales, number of employees and so on have been used in other articles. The amount of discretionary accruals were too small compared to the amount of total assets, so authors decided to use natural logarithm of total assets. Also other members (Qichun Wu, Abdul Qadeer) from the academic community recommend this indicator for firm size measurement.

The hypothesis was derived from the research question: Is there a statistical difference in the level of EM regarding firm size?

To verified hypothesis, the one-way ANOVA test was used.

$$
\begin{gathered}
S S T=S S B+S S E \\
\sum_{i=1}^{n}\left(x_{i}-\bar{x}\right)^{2}=\sum_{j=1}^{k}\left(\overline{x_{j}}-\bar{x}\right)^{2} n_{j}+\sum_{i=1}^{n_{j}} \sum_{j=1}^{k}\left(x_{i}-\overline{x_{j}}\right)^{2}
\end{gathered}
$$

Where:

$\begin{array}{ll}x_{i} & \text { i-th value of interval variable } \\ n & \text { sample size } \\ \bar{x} & \text { mean } \\ n_{j} & \text { the frequency of the } \mathrm{j} \text {-th group } \\ k & \text { the number of nominal variable groups } \\ \bar{x}_{j} & \text { mean } \mathrm{j} \text {-th group }\end{array}$

The estimate of intergroup (MSB) and intragroup (MSE) variance can then be expressed as the ratio between the sum of squares and the corresponding number of degrees of freedom.

$$
\begin{aligned}
& M S B=\frac{S S B}{k-1} \\
& M S E=\frac{S S E}{n-k}
\end{aligned}
$$


By using a test statistic that has Fisher's F-distribution with degrees of freedom $v_{1}=k-1$ and $v_{2}=n-k$ which equals the share of intergroup and intragroup variance $F=\frac{M S B}{M S E}$, we decide about not reject or reject the null hypothesis. The second possible decision criterion is based on the achieved $p$-value, which we compare with the chosen level of significance. This was determined by using statistical analysis software in Excel XLSTAT. If the $p$-value at the selected significance level $\alpha=0.05$ is less than 0.05 , this means that the differences in the sample averages are too large to be random, we reject $\mathrm{H} 0$ and do not reject $\mathrm{H} 1$, which state of the existence of a statistically significant difference in the level of earnings management regarding to firm size.

\section{Results and Discussion}

As was mentioned above, authors used the Amadeus database to obtain data for their research. Sample consists of 1,950 companies operated on emerging market during the year 2018. In the first step, the variables needed for the next steps were calculated. The sum of total accruals was calculated according to the formula 1 , then the variables needed for DA estimation based on the modified Jones model were calculated. Due to sample size, Table 2 shows only a preview of the calculated variable in the first five companies of the sample.

Table 2

A preview of the calculated variable. Source: own research

\begin{tabular}{|l|c|c|c|c|}
\hline \multirow{2}{*}{ Company } & \multicolumn{4}{|c|}{ Variables } \\
\cline { 2 - 5 } & $\frac{\boldsymbol{T} \boldsymbol{A}_{\boldsymbol{i t}}}{\boldsymbol{A}_{\mathbf{i t}-\mathbf{1}}}$ & $\frac{\mathbf{1}}{\boldsymbol{A}_{\mathbf{i t}-\mathbf{1}}}$ & $\frac{\Delta \boldsymbol{R E V _ { i t }}-\boldsymbol{\Delta R E \boldsymbol { C } _ { \boldsymbol { i t } }}}{\boldsymbol{A}_{\boldsymbol{i t}-\mathbf{1}}}$ & $\frac{\boldsymbol{P P E}_{\boldsymbol{i t}}}{\boldsymbol{A}_{\boldsymbol{i t}-\mathbf{1}}}$ \\
\hline Company 1 & 0.0121744 & 0.0000085 & 0.2197624 & 0.5399518 \\
\hline Company 2 & 0.0703312 & 0.0000300 & 0.1238191 & 0.0204686 \\
\hline Company 3 & 0.0665522 & 0.0000186 & 0.1489563 & 0.0194390 \\
\hline Company 4 & -0.0320197 & 0.0000065 & 0.0400184 & 0.8336340 \\
\hline Company 5 & 0.0855861 & 0.0000243 & -0.0375922 & 0.2875401 \\
\hline
\end{tabular}

The values of variables showed a striking deviation from the others. Such values are also known as outliers, and it is recommended to exclude them from the database because it can falsify the results of the other analyses. For this reason, authors decided to proceed to the exclusion of extreme values. Results from a survey conducted within database without extreme values - "outliers" can be considered more relevant. There are several known methods for outliersexclusion. To identify outliers the two-sided Grubbs' test was used. It is defined for the hypothesis:

$\mathrm{H}_{0} \quad$ There are no outliers in the data set

$\mathrm{H}_{\mathrm{a}} \quad$ There is at least one outlier in the data set 
The significance level was set at $\alpha=0.05$. Companies whose values in some of the variables were marked as outliers were excluded from the database.The remaining number of enterprises was 1,548 .

As was mentioned above, the modified Jones model sets DA as residuals from a regression of total accruals. The following Tables (3-5), show the results of regression.

Table 3

Regression Statistics. Source: own research

\begin{tabular}{|l|l|}
\hline Multiple R & 0.320 \\
\hline R Square & 0.103 \\
\hline Adjusted R Square & 0.101 \\
\hline Standard Error & 0.144 \\
\hline Observations & 1,548 \\
\hline
\end{tabular}

Table 4

Regression Results. Source: own research

\begin{tabular}{|c|c|c|c|c|c|c|}
\hline & Coef. & $\begin{array}{c}\text { Standard } \\
\text { Error }\end{array}$ & $\mathrm{t}$ Stat & $\begin{array}{c}\mathrm{P}- \\
\text { value }\end{array}$ & $\begin{array}{c}\text { Lower } \\
95 \%\end{array}$ & $\begin{array}{c}\text { Upper } \\
95 \%\end{array}$ \\
\hline Intercept & 0.035 & 0.009 & 4.069 & 0.000 & 0.018 & 0.052 \\
\hline$\frac{1}{A_{\text {it-1 }}}$ & -273.736 & 57.613 & -4.751 & 0.000 & $\begin{array}{c}- \\
386.745\end{array}$ & $\begin{array}{c}- \\
160.728\end{array}$ \\
\hline$\frac{\Delta R E V_{i t}-\Delta R E C_{i t}}{A_{i t-1}}$ & -0.037 & 0.009 & -4.190 & 0.000 & -0.055 & -0.020 \\
\hline$\frac{P P E_{i t}}{A_{i t-1}}$ & -0.168 & 0.014 & - & 0.000 & -0.196 & -0.140 \\
\hline
\end{tabular}

Table 5

A preview of residuals. Source: own research

\begin{tabular}{|l|l|l|}
\hline Observation & Predicted Y & Residuals \\
\hline Company 1 & 0.010 & -0.158 \\
\hline Company 2 & -0.024 & -0.119 \\
\hline Company 3 & 0.018 & 0.062 \\
\hline Company 4 & -0.004 & -0.042 \\
\hline Company 5 & 0.008 & -0.231 \\
\hline$\ldots$ & $\ldots$ & $\ldots$ \\
\hline
\end{tabular}

The aim of the contribution is EM initiatives analysis, statistical verification of the existence of the relationship between EM and company size defined by chosen criteria and providing conclusion with regard to results. After the calculation of DA according to the techniques described above, the hypothesis was verified. To verified hypothesis, the one-way ANOVA test was used. The results of ANOVA are shown in Tables 6-7. 
Table 6

ANOVA. Source: own research

\begin{tabular}{|l|l|l|l|l|}
\hline Groups & Count & Sum & Average & Variance \\
\hline Residuals & 1,548 & $-2.8 \mathrm{E}-14$ & $-1.8 \mathrm{E}-17$ & 0.021 \\
\hline $\begin{array}{l}\text { Natural } \\
\text { logarithm of } \\
\text { total assets }\end{array}$ & 1,548 & -14741.5 & -9.52294 & 0.681 \\
\hline
\end{tabular}

Table 7

ANOVA. Source: own research

\begin{tabular}{|l|l|l|l|l|l|l|}
\hline $\begin{array}{l}\text { Source of } \\
\text { Variation }\end{array}$ & SS & df & MS & F & P-value & F crit \\
\hline $\begin{array}{l}\text { Between } \\
\text { Groups }\end{array}$ & $7,0191.28$ & 1 & 70191.28 & 200147.3 & 0.000 & 3.844466 \\
\hline $\begin{array}{l}\text { Within } \\
\text { Groups }\end{array}$ & $1,085.06$ & 3094 & 0.350698 & & & \\
\hline Total & 71276.34 & 3095 & & & & \\
\hline
\end{tabular}

The results mean that the differences in the sample averages are too large to be random, we reject $\mathrm{H}_{0}$ and do not reject $\mathrm{H}_{\mathrm{a}}$, which state of the existence of a statistically significant difference in the level of earnings management regarding to firm size. $(p-$ value $(0.000)<\alpha(0.05))$

\section{Conclusions}

Current studies highlight the importance of the role of EM initiatives, mainly in relation to reliability of the financial reports. The aim of this contribution is EM initiatives analysis and the statistical verification of the existence of the relationship between EM and company size, defined by chosen criteria and provide conclusions, with regard to the results. Within the practical part of the work herein, authors tried to detect the presence of EM, based on the calculation of accruals structured, as discretionary and non-discretionary accruals in the sample of enterprises using modified Jones model and to identify the relationship between EM and company size, using the one-way ANOVA test. Based on the results, it can be stated that the Authors confirmed the existence of EM in emerging markets. According to the one-way ANOVA test, it can be also confirmed that there is a statistically significant relationship between the level of EM initiatives and company size. The resulting sample of enterprises will become the basis for the relevance of models developed for earnings management in the V4, within futures research. So first, there is evidence of earnings management initiatives in the market of $\mathrm{v} 4$ countries and second, there is dependence between the EM iniciatives and firm size. The final findings, based on a comparison of the achieved results SMEs and large enterprises, are as follows:

- $58.35 \%$ of large companies managed profit by increasing it

- $36.98 \%$ SMEs managed the profit by increasing it 
- By applying EM initiatives, large companies increased profits more significantly than SMEs

- By applying EM initiatives, SMEs reduced profits more significantly than large companies

- For large companies, the average value of positive DA reached the value 0.047

- For SMEs, the average value of positive DA reached the value 0.031

- For large companies, the average value of negative DA reached the value 0.038

- $\quad$ For SMEs, the average value of positive DA reached the value 0.051

These findings should be taken into account when creating a comprehensive model of EM that may vary, depending on the size of the entity.

\section{Acknowledgement}

This paper was financially supported by the Slovak Research and Development Agency - Grant NO. APVV-17-0546 Variant Comprehensive Model of Earnings Management in Conditions of The Slovak Republic as an Essential Instrument of Market Uncertainty Reduction.

\section{References}

[1] Rath, S., \& Sun, L. (2008) The Development of Earnings Management Research. International Review of Business Research Papers, 4(2), 265-277

[2] Ball, R. (1972) Changes in accounting techniques and stock prices. Journal of Accounting Research, 10, 1-41, http://dx.doi.org/10.2307/2489860

[3] Kaplan, R. S., \& Roll, R. (1972) Investor evaluation of accounting information - some empirical evidence. Journal of Business, 45(2), 225257. http://dx.doi.org/10.1086/295446

[4] Janoskova, K., \& Kral, P. (2019) An In-Depth Analysis of the Summary Innovation Index in the V4 Countries. Journal of Competitiveness, 11(2), 68-83. https://doi.org/10.7441/joc.2019.02.05

[5] Mayer-Sommer, A. P. (1979) Understanding and acceptance of the efficient markets hypothesis and its accounting implications. Accounting Review, 54(1), 88-106

[6] Fama, E. F. (1970) Efficient capital markets: a review of theory and empirical work, The Journal of Finance, 25, 383-417, http://dx.doi.org/10.2307/2325486

[7] Rahman, A., Rozsa, Z., \& Cepel, M. (2018) Trade Credit and Bank Finance - Evidence from the Visegrad Group. Journal of Competitiveness, 10(3), 132-148, https://doi.org/10.7441/joc.2018.03.09 
[8] Behun, M., Gavurova, B., Tkacova, A., \& Kotaskova, A. (2018) The Impact of the Manufacturing Industry in the Economic Cycle of European Union Countries. Journal of Competitiveness, 10(1), 23-39, 10.7441/joc.2018.01.02

[9] Watts, R., \& Zimmerman, J. L. (1978) Towards a positive theory of the determination of accounting standards. The Accounting Review, 53, 112134

[10] Valaskova, K., Kliestik, T., Svabova, L., \& Adamko, P. (2018) Financial Risk Measurement and Prediction Modelling for Sustainable Development of Business Entities Using Regression Analysis. Sustainability, 10(7), http://dx.doi.org/10.3390/su10072144

[11] Salaga, J., Bartosova, V., \& Kicova, E. (2015) Economic Value Added as a measurement tool of financial performance. Procedia Economics and Finance, 26, 484-489

[12] Cox, C. T. (1987) Earnings variability, firm size, and the informationcontent in management forecasts of annual earnings. Journal of Accounting and Public Policy, 6(2), 139-153, 10.1016/0278-4254(87)90010-X

[13] Siregar, S. V., \& Utama, S. (2008) Type of earnings management and the effect of ownership structure, firm size, and corporate-governance practices: Evidence from Indonesia. The International Journal of Accounting, 43(1), 1-27, 10.1016/j.intacc.2008.01.001

[14] Purnama, I., \& Nurdiniah, D. (2018) Profitability, Firm Size, and Earnings Management: the Moderating Effect of Managerial Ownership, $5^{\text {th }}$ Annual International Conference on Accounting Research (AICAR) Manado, Indonesia, 41-46

[15] Turegun, N. (2018) Effects of borrowing costs, firm size, and characteristics of board of directors on earnings management types: a study at Borsa Istanbul. Asia-Pacific Journal of Accounting and Economics, 25(1-2), 42-56. 10.1080/16081625.2016.1246192

[16] Ratnawati, V., Hamid, M. A. A., \& Popoola, O. M. J. (2016) The Interaction Effect of Institutional Ownership and Firm Size on the Relationship between Managerial Ownership and Earnings Management. $3^{\text {rd }}$ International Conference on Accounting Studies (ICAS). Malaysia, 177183

[17] Shu, P. G., \& Chiang, S. J. (2014) Firm size, timing, and earnings management of seasoned equity offerings. International Review of Economic and Finance, 29, 177-194, 10.1016/j.iref.2013.05.011

[18] Rajnoha, R., \& Lorincova, S. (2015) Strategic Management of Business Performance Based on Innovations and Information Support in Specific Conditions of Slovakia. Journal of Competitiveness, 7(1) 3-21, 10.7441/joc.2015.01.01 
[19] Rădulescu, A. (2018) Users' Social Trust of Sharing Data with Companies: Online Privacy Protection Behavior, Customer Perceived Value, and Continuous Usage Intention. Contemporary Readings in Law and Social Justice, 10(1), 137-143

[20] Hudakova, M., Masar, M., Luskova, M., \& Patak M. R. (2018) The Dependence of Perceived Business Risks on the Size of SMEs. Journal of Competitiveness, 10(4), 54-69, https://doi.org/10.7441/joc.2018.04.04

[21] Burgstahler, D., \& Dichev, I. (1997) Earnings management to avoid earnings decreases and losses. Journal of Accounting and Economics, 24(1), 9-126, 10.1016/S0165-4101(97)00017-7

[22] Rangan, S. (1998) Earnings management and the performance of seasoned equity offerings. Journal of Financial Economics, 50(1) 101-122, 10.1016/S0304-405X(98)00033-6

[23] Lee, B. B., \& Choi, B. (2002) Company size, auditor type and earnings management. Journal of Forensic Accounting, 3, 27-50

[24] Kim, S. H., Udawatte, P., \& Yin, J. (2019) The Effects of Corporate Social Responsibility on Real and Accrual-based Earnings Management: Evidence from China. Autralian Accounting Review, 29(3), 580-594, http://dx.doi.org/10.1111/auar.12235

[25] Cho, H. J., Choi, S. \& Kwon, D. H. (2019) Employee tenure and earnings management through real activities manipulation. Asia-Pacific Journal of Accounting and Economics, will be published. http://dx.doi.org/10.1080/16081625.2019.1694953

[26] Hamza, S. E., \& Kortas, N. (2019) The interaction between accounting and real earnings management using simultaneous equation model with panel data. Review of Quantitative Finance and Accounting, 54(4), 1195-1227, http://dx.doi.org/10.1007/s11156-018-0779-5

[27] Jeong, K. H., \& Choi, S. U. (2019) Does Real Activities Management Influence Earnings Quality and Stock Returns in Emerging Markets? Evidence from Korea. Emerging Markets Finance and Trade, 55(12), 2834-2850, http://dx.doi.org/10.1080/1540496X.2018.1535970

[28] Hoglund, H. (2012) Detecting earnings management with neural networks. Expert Systems with Applications, 39(10), 9564-9570, 10.1016/j.eswa.2012.02.096

[29] Rahman, A., Belas, J., Kliestik, T., \& Tyll, L. (2017) Collateral requirements for SME loans: empirical evidence from the Visegrad countries, Journal of Business Economics and Management, 18(4), 650$675,10.3846 / 16111699.2017 .1357050$

[30] Belas, J., \& Sopkova, G. (2016) A Model of Entrepreneurial Orientation. Transformation in Business \& Economics, 15(2B) (38B), 630-645 
[31] Llukani, T. (2013) Earnings management and firm size: an empirical analyze in Albanian market. European Scientific Journal, 9(16), 135-143

[32] Ronen, J., \& Yaari, V. (2008) Earnings Management. US: Springer

[33] Chang, H-Y., Liang, L-H., \& Yu, H-F. (2019) Market power, competition and earnings management: accrual-based activities. Journal of Financial Economic Policy, 11(3), 368-384, 10.1108/JFEP-08-2018-0108

[34] Hsieh, Y-T., Chen, T-K., Tseng, Y-J., \& Lin, R-C. (2018) Top Management Team Characteristics and Accrual-Based Earnings Management. International Journal of Accounting, 53(4), 341-334, 10.1016/j.intacc.2018.11.004

[35] Anagnostopoulou, S. C., \& Tsekrekos, A. E. (2017) The effect of financial leverage on real and accrual-based earnings management. Accounting and Business Research, 47(2), 191-236, 10.1080/00014788.2016.1204217

[36] Kovacova, M., \& Kliestik, T. (2017) Logit and Probit application for the prediction of bankruptcy in Slovak companies. Equilibrium. Quarterly Journal of Economics and Economic Policy, 12(4), 775-791, http://dx.doi.org/10.24136/eq.v12i4.40

[37] Sadaf, R., Olah, J., Popp, J., \& Mate, D. (2018) An Investigation of the Influence of the Worldwide Governance and Competitiveness on Accounting Fraud Cases: A Cross-Country Perspective. Sustainability, 10(3), 1-11, http://dx.doi.org/10.3390/su10030588

[38] Valaskova, K., Kliestik, T., \& Kovacova, M. (2018) Management of financial risks in Slovak enterprises using regression analysis. Oeconomia Copernicana, 9(1), 105-121, http://dx.doi.org/10.24136/oc.2018.006

[39] Belas, J., Smrcka, L., Gavurova, B., \& Dvorsky, J. (2018) The Impact of Social and Economic Factors in the Credit Risk Management of SME. Technological and Economic Development of Economy, 24(3), 1215-1230

[40] Roychowdhury, S. (2006) Earnings management through real activities manipulation. Journal of Accounting and Economics, 42(3), 335-370, 10.1016/j.jacceco.2006.01.002

[41] Graham, J. R., Harvey, C. R., \& Rajgopal, S. (2005) The economic implications of corporate financial reporting. Journal of Accounting and Economics, 40, 3-73, http://dx.doi.org/10.2139/ssrn.491627

[42] Svabova, L., Kramarova, K., \& Durica, M. (2018) Prediction model of firm's financial distress. Ekonomicko-manazerske spektrum, 12(1), 16-29

[43] Fanelli, V., \& Ryden. A. K. (2018) Pricing a Swing Contract in a Gas Sale Company. Economics, Management, and Financial Markets, 13(2), 40-55 
[44] Belas, J., Gavurova, B., \& Toth, P. (2018) Impact of selected characteristics of SMES on the capital structure. Journal of Business Economics and Management, 19(4), 592-608

[45] El Diri, M. (2018) Introduction to Earnings Management. US: Springer

[46] Dechow, P. M., Sloan, R. G., \& Sweeney, A. P. (1995) Detecting Earnings Management. The Accounting Review, 70(2), 193-225 